\title{
Analysis of Heir Pre-Investigation Mechanism: According to Shari'ah Perspective
}

\author{
Md Yazid Ahmad \\ Universiti Kebangsaan Malaysia \\ Email: zeeyad08@hotmail.com \\ Nor Yani Isa \\ Universiti Kebangsaan Malaysia \\ Email:nur_inayah1109@yahoo.com \\ Anwar Fakhri Omar \\ Universiti Kebangsaan Malaysia \\ Email: afbo67@gmail.com
}

Doi:10.5901/mjss.2014.v5n29p107

\begin{abstract}
Determination of the rightful heirs and portions of inheritance is the main objective of Islamic Inheritance Law in order for the rightful heirs to receive their justice. Therefore, there are many processes to go through such as investigation and legal hearing (should there be a claim) before a decision is made and verified. However, before reaching that, heir pre-investigation mechanism must be applied comprehensively so that the subsequent processes can be implemented smoothly and effectively. The main objective of this article is to analyse the position of heir pre-investigation basic mechanisms and the extent to which they are applied in matters related to Muslim inheritance issues according to shari'ah. Even though there is neither specific nor systematic pre-investigation mechanism formally established to follow the shariah, however, from the angle its practice, the foundations which shape the mechanisms are indeed existent and have been practised indirectly by the Messenger of Allah and his Companions as well as the tabicin.
\end{abstract}

Keywords: mechanism; pre-investigation; heir; inheritance; shariah;

\section{Introduction}

The Islamic Inheritance Law contains rules which arrange processes related to inheritance left by the deceased to the rightful and living heirs after the liabilities of the properties are settled. However, not all inheritors will receive the inheritance left by the deceased if due investigation process is done to each and every one of them. This is so because of the possibility that can cause obstruction for the heirs from gaining the inheritance from the dead. Implementation of investigation mechanism on inheritors in Islam is an important process to know the veracity and validity of an heir thus generating actions and decisions that are appropriate and accurate so as to avoid mistreatment of the deceased and the entitled heirs. Allah emphasised much importance of conducting investigation on receiving news and updates from a fasiq (wicked) before concluding a ruling as described in His words in verse 6 in Chapter al-Hujurat.

Therefore, prior to any proper investigation being made, there are several methods of pre-investigation on the heirs which need to be fulfilled so as to smoothen and facilitate the real investigation process. Although there was neither specific nor systematic pre-investigation mechanism of inheritance formally established by shari'ah, but in practice it has been exercised indirectly by the Prophet Muhammad (peace be upon him) and his Companions as well as tabicin before undertaking the process of investigation and determination of heirs entitled to inheritance. The pre-inquiry mechanism of inheritance is focused on methods to retrieve and collect relevant information that can be used as an argument or evidence in the event of a claim or dispute in a legal hearing. 


\section{Definition}

Investigation in Arabic is tahqiq, derived from the root word al-haqq, which carries the meaning truth or opposite of falsehood. Tahqiq definition is "of honesty and truthful words (al-Razi, 1993, pp. 86). In terms of terminology, tahqiq means the evidence of conviction of a case based on their arguments which clarifies things for authorization purpose (alJurjani, 1996, pp. 79). Based on the above explanation, the term 'pre-investigation' can be defined as a condition before any actual inspection or research is done on a matter to know its decision and validity.

\section{The Importance of Pre-Investigation Mechanism}

Investigation is an important process to examine and evaluate details and evidences to bring forth the truth in any decision made. This process is also important in building up relevant evidences from the obtained information as solid argument in a hearing (if any) should there be a claim and dispute so that justice is served. Therefore, in obtaining the relevant information and evidence, a process named as 'pre-investigation' must be carried out before the actual investigation to ease the next course of actions. The same goes in the question of inheriting a property. Decision on the legitimate heirs to an inheritance and the proportion they are entitled to should be done through a process of preinvestigation conducted by a party having jurisdiction over the matter in order to facilitate the following investigation to determine whether the heirs are entitled to the estate or not, and the proportion of each. Allah SWT has also expressed the importance of conducting research or investigation prior to making a decision as stated in al-Qur'an, al-Hujurat 49:6 which means:

O you who have believed, if there comes to you a fasiq with information, investigate, lest you harm a people out of ignorance and become, over what you have done, regretful.

The reason for revelation of this verse (sababun nuzul) was as narrated that the Messenger of Allah PBUH had sent al-Walid bin 'Uqbah to take zakat property collected by al-Harith ibn Dirar. Then al-Walid went to the place where alHarith was. However, on the way there, he changed course and returned to Medina. Having met the Prophet, he said; "Al-Harith did not want to surrender the property zakat, he even wanted to kill me". Hearing the story, the Prophet sent another delegation to meet with al-Harith. En route, al-Harith and his companions met with the representatives of the Prophet. Al-Harith said to them; "Where are you sent to?" They answered; "We have been sent to meet you". Al-Harith asked again; "For what?" They answered again; "The Messenger of Allah sent al-Walid ibn 'Uqbah to see you. Then he stated that you did not want to surrender the property zakat, even saying you want to kill him". Al-Harith said, "By Him who has sent Muhammad to lead the religion of truth, I never saw him and he never came to me!" After al-Harith met the Prophet, he asked: "You did not want to surrender the property zakat and wanted to kill my messenger?" Al-Harith responded, "No! By Him who has sent you to bring the religion of truth, I never saw him and he never came to me." (Ibn Hanbal, Undated, 4: 279, no. 18482).

Meanwhile Ibn 'Abbas said: "The Prophet sent al-Walid bin 'Uqbah to Bani al-Mustaliq to take alms from them. When they heard of the arrival of the Messenger Prophet Muhammad, they were very happy and were out in droves to see him. When al-Walid knew they were out in droves to see him, his heart was restless and he felt afraid and so he went back to see the Prophet and said: "O Messenger of Allah, verily Bani al-Mustaliq refused to pay zakat." Hearing the news, the Messenger of Allah PBUH was very angry and while in his heart he wanted to fight them, came to him a messenger from them and said: "O Messenger of Allah, we heard that your messenger turned back halfway. We fear his return and a letter would come to us from you because you are angry. Indeed, we seek refuge from the anger of Allah and His Messenger". Then Allah revealed the verses above understandable (al-Bayhaqi, 1344H, 2: 76, no. 18371). Based on that verse, it can be understood that before a decision is reached, pre-investigation process must be gone through first to get enough information and then the actual investigation can be done as best as possible so that the action taken is correct and accurate thus avoiding mistreatment of any party.

Similarly, in the case of an inheritance problem whereby the heirs of the deceased come to make a claim on the inheritance, pre-investigation mechanism is applied first in which the involved officials find and collect sufficient relevant details or data. Only then can the investigation of the heirs and scrutiny of all evidence and information be conducted carefully and thoroughly to avoid data confusion in decision-making on the entitlement of the beneficiaries to the inheritance. Thus, it can be understood that pre-investigation mechanism is a very important process and gives an effect to the investigation to determine a decision. If investigation is not done using a sound pre-investigation procedure, then truth cannot be established and in fact falsehood will be relied upon in deciding the verdict about to be finalised by the 
relevant party.

\section{Application of Heir Pre-investigation Mechanism}

Islam is a holistic religion and covers all life aspects of mankind. Apart from emphasising aspects of creed, worship and morality, there are other aspects which are given priority in order to guarantee continuation of life of the whole mankind. In this matter, Islam also provides pre-inquiry mechanism which had been indirectly applied since the time of the Messenger of Allah PBUH and his Companions as well as the tabicin, albeit unsystematic and in disorganised manner. Pre-investigation mechanism of inheritance is very important in order to get and gather information so that investigation can be carried out smoothly and effectively, building and developing a solid argument before a decision is finalized. And in the case related to the issue of heir, this process can ensure only beneficiaries who really deserve and are entitled to the inheritance inherit the estate left by the deceased. If not done carefully, it will definitely cause a variety of problems to arise that will lead to injustice.

The use of ijtihad during the time of the Companions and the tabicin led to some forms of figh understanding in the process of inheritance distribution. This gave rise to several figh mazhabs and influenced the practice of inheritance apportionment to Muslims of different denomination. Undeniably this difference occurred because the Companions and tabicin at that time were very careful about ascertaining legitimate beneficiaries of inheritance and the portion they should get based on al-Qur'an and al-Sunnah as well as ijtihad among them, if such problem case never arose in the time of the Messenger of Allah PBUH. Indeed, the problem related to inheritance is very important to be well understood by the Companions and former tabicin before doing ijtihad and making a decision. This was because it can give huge implications in matters of Islamic inheritance law in the future. There are some heir pre-investigation methods that have been adopted heir before doing the actual investigation in order to get the right decisions regarding the status of the heir and their respective allocation, among which are:

\subsection{Method of Information Gathering Through Complaint}

In a hadith narrated by Abu Dawud, al-Tirmidhi, Ibn Majah and other transmissions, from 'Abdullah ibn Muhammad bin 'Aqil from Jabir who said: "The wife of Sa'd ibn al-Rabi' came to see the Messenger of Allah PBUH and said: "Oh Messenger of Allah! These are the two daughters of Sa'd ibn al-Rabi'. Their father was martyred fighting alongside you in the Battle of Uhud, and their uncle has taken all their properties without leaving any to them. And surely they cannot get married unless they have a property." The Messenger of Allah said, "Allah will send down His law on the matter." Then the verse on division of inheritance descended as stated above, and the Messenger of Allah PBUH sent people to call the uncle of the two and said to them, which means: "Give the two daughters of Sa'd two-thirds and to their mother oneeighth and the remainder is for you". (al-Bayhaqi, 1344H, 6: 216, no. 11999).

Based on the above hadith, it can be explained that it is important to know who the heirs who will inherit the deceased's estate are. To know the position of the heir whether or not the heir is entitled to get either small or big proportion of the estate, pre-investigation mechanism of inheritance based on the method of information gathering should be done so that a detailed investigation which is to be done can prevent incomplete information from the point of that no heir is dropped from the recipient list of the estate. Through the prevailing situation as described in the above hadith also, the deceased family members should immediately, upon death, seek a legal certainty regarding the law of faraid on every living heir to ensure the distribution of inheritance can be done in a fair and equitable manner.

According to Ibn 'Abbas during the age of jahiliyyah, sons and daughters could not inherit until they reach the age of maturity. When an Ansar man named Aws ibn Thabit died, he left behind two daughters and a son who were still kids. At that time, two children of their uncle (cousin of Aws), Khalid and Arfatah came and took all of the inheritance. So, the widow of Aws went to see the Messenger of Allah PBUH and told him of the incident (al-Baqqa'i, Undated, 5: 244). Therefore, a verse of al-Qur'an was revealed as in Chapter al-Nisa' 4: 7 which means:

For men is a share of what the parents and close relatives leave, and for women is a share of what the parents and close relatives leave, be it little or much - an obligatory share.

\subsection{The Method of Sending Letters}

There are several hadith and athar which tell how pre-investigation mechanism via method of sending of letters was used by the Companions and tabicin before the process of investigation on eligible beneficiaries of the inheritance. It was 
narrated that a man shot an arrow to Sahl ibn Hunayf and killed him and he left no heir except an uncle from his mother's side. So, Abu 'Ubaydah ibn al-Jarrah sent a letter to Saidina 'Umar ibn al-Khattab to ask about who would inherit the wealth of Sahl ibn Hunayf who did not have any relative except his uncle from his mother's side. Saidina 'Umar then replied with a letter by answering that the Messenger of Allah PBUH had said that Allah and His Messenger are the guardians to all who do not have a guardian and an uncle from mother's side is a guardian (wali) for him who has no guardian" (al-Bayhaqi, 1344H, 2: 154, no. 12570). Based on the hadith, it can be explained that Abu "Ubaydah sent a letter to Saidina "Umar to obtain an information about who was eligible for the estate of the deceased. This showed that sending of a letter was a method of heir pre-investigation in Islam. This method was used by the Companions to identify heirs who would inherit the properties of the deceased.

Moreover, there is another hadith which also tells about the means used by the Companions to get details for deciding the inheritance proportion among the heirs involved, which is: "It was related to me by Yahya from Malik from Yahya bin Sa'id that it has come to him that Mu'awiyah ibn Abi Sufyan wrote a letter to Zayd bin Thabit asking about the share of inheritance for a grandfather. Zayd bin Thabit then replied: "You have written a letter to me by asking about the share of a grandfather in inheritance. Allah is more knowing, because such matter has not been decided before except by the Amirs who were Caliphs. I have lived with two Caliphs before you; the second gave half of the share to a grandfather with a brother and one-third if with two brothers. If the number of brothers is higher, then it is not reduced to less than one-third of the inheritance (Ibn Anas, 2004, 3: 728).

Through an understanding of the story told above, Mu'awiya also used the technique of sending the letter as a beneficiary pre-investigation to determine the actual proportion to be granted to the grandfather from the properties of the deceased. This method was one of the pre-investigation mechanisms often used by the Companions and tabicin to obtain and collect information which were to be used in conducting the investigation to solve the problems that arose in their time. They sent letters also because they wanted to get a certainty about who were the eligible beneficiaries and the distribution of properties the beneficiaries will get before deciding the law of faraid in problems posed to them.

\subsection{Method of Narration}

In connection with this method of narration, there is a history which explains its position in relation to the beneficiary dhawi al-arham as follows: "It was narrated to me by Ishaq bin Ibrahim saying, I said to Abu Usamah, who told you Idris, who narrated to us Talhah from Sa'id bin Jubayr from Ibn 'Abbas, on the verse: "And for all, We have made heirs to what is left by parents and relatives. And to those whom your oaths have bound [to you] - give them their share. Indeed Allah is ever, over all things, a Witness". Ibn "Abbas said, "When the emigrants came to the Prophet in Medina, the emigrant would inherit the Ansar while the latter's relatives would not inherit him because of the bond of brotherhood which the Prophet established between them (i.e. the Muhajirin and the Ansar). When the verse: "And to everyone We have appointed heirs.." (Chapter al-Nisa':33) was revealed, Allah abrogated with the verse: "And to those whom your oaths have bound [to you]" (Abu Dawud, Undated, 2: 143, no. 2922).

The above hadith explains the law regarding dhawi al-arham i.e. whether they are entitled to inherit or not. According to Imam al-Bukhari, when the Muhajirin came to Medina, the Ansar inherited those Muhajirin who had no blood relationship because of the brotherhood between them made by the Prophet. The meaning of the hadith was that The Prophet (p.b.u.h.) had made a brotherhood between the Muhajirin and the Ansar, so they inherited each other due to the bond of brotherhood. However, after the revelation by Allah concerning inheritance from among relatives, inheritance among those who swear allegiance to each other was abolished, but the elements of mutual help, protection and wills for them remained there (al-'Asqalani, 2000, 13: 517).

This situation shows that after the Messenger of Allah PBUH had brought together between Muhajirin and Ansar, they considered themselves to be guardians to each other and would inherit properties if one of them died. However, after the verse of al-Qur'an on inheritance had been revealed with the information on heirs eligible for inheritance and the respective proportion they should get, the practice of inheritance between them was abolished. In this situation, in order to ensure that only the rightful heirs get the inheritance, careful investigation using information gathered through a proper pre-investigation mechanism were conducted so as to avoid injustice in inheritance distribution from occurring because there were concerns that inheritance were distributed among the Muhajirin and the Ansar who were not in the list of heirs to the deceased.

\subsection{Method of Questioning}

In addition, method of questioning is also one of the components of pre-investigation mechanism which had been used by 
the Companions themselves. This situation can be seen in a hadith which shows a method of questioning used by the Companions to get necessary information to determine the proportion of inheritance beneficiaries should get. This practice is clearly depicted in a hadith in which it was narrated that Huzayl ibn Shurahbil said: "A man came to Abu Musa al-Ash'ari and Salman ibn Rabi'ah al-Bahili and asked them about the share (of inheritance) for a daughter, a daughter to a son (granddaughter), and a sister from the same father and mother." They said: "A daughter will get half, and the remainder is given to sister from the same father and mother." They added: "Go to Ibn Mas'ud, for he will agree with what we say." So, the man went to Ibn Mas'ud and told him what had been said by them. 'Abdullah said: "I would go astray and be confused if I say that I agree; but I will decide as the Messenger of Allah made the decision. A daughter gets one half, a daughter to a son gets one-sixth and what is left is given to the sister from the same father and mother (al-Bukhari, 1422H, no. 6736).

The above opinion of the two companions was likely based on the principle that if there is a closer relative, then the more distant relative will not get any part. Therefore, with the presence of a daughter, they took away the part of the granddaughter's and the balance of the estate was given to the sister of the same parents. But if the heirs of the deceased are only two daughters, then they will get a fixed share which is two-thirds of the estate and if there was no daughter, a share will be given to the granddaughter. In this situation, the daughter and the granddaughter will not the same share due to their relation to the deceased being different ('Ali Za'i, 2007, pp. 20).

On analysing the above hadith, the pre-investigation mechanism on heirs which was used in this case was through the method of questions, directly asked to the Companions who were proficient in determining faraid law. The question presented was intended to determine the proportion for beneficiaries who will receive the estate of the deceased. Such method was the norm among the people of that time because in the event of death they would come straight to the Companions to ask about the law of faraid upon all living heirs.

\subsection{Method of Collection of Written Documents}

Other than the methods stated above, the method of collecting relevant written documents by the entrusted party is of significance as a preparation when a claim or dispute happens. These written documents can be used as supporting evidence in the investigation and also in a hearing. Shari'ah recognition regarding the importance of written document is clearly noted in al-Qur'an, Chapter al-Baqarah, 2: 282 which means:

O you who have believed, when you contract a debt for a specified term, write it down. And let a scribe write [it] between you in justice. Let no scribe refuse to write as Allah has taught him.

In a hadith of the Messenger of Allah PBUH, Imam al-Bukhari stated from Ibn 'Abbas that Rasulullah PBUH wrote to the rulers of Khaybar and Rome with writing with a seal (Ibn Hajar, 1959, 8:260). Hence, that was an explicit recognition given to signed written document as something that has high reliability including its use as an argument or evidence in the court. With regard to the importance of written documents, the jurists have agreed to accept the necessity of a signed written document as evidence (al-Zuhayli, 1996, 6: 786) in the judicial process in the event of a claim or dispute. Hence, in deciding a right of inheritance, this recognition also applies to official documents signed with government's official stamps which customarily are preserved and difficult to forge and alter (Ibn 'Abidin, Undated, pp. 413). The same matter is stated in Majallat al-Ahkam al-'Adliyyah, Items 1736 and 1737 which give the provision that, if a stamped written document is protected from fraud and forgery, it can be used as a basis for conviction. This includes official government official documents. Therefore, the justification for the method of collecting written document as one of the important mechanism of inheritance pre-investigations is that all relevant documents collected can be used as evidence or argument in a trial in the event of a claim or dispute.

\section{Conclusion}

The right of heirs to inheritance is guaranteed in Islam as stipulated in al-Qur'an, al-Sunnah and consensus of the Companions. Therefore, inherited property will transfer directly and this right can be claimed should any injustice occur. The heirs are eligible to receive their allocation based on some conditions and reasons which enable them to inherit from the deceased. However, if there are certain obstacles as specified by shari'ah evidence, then they are automatically prevented from receiving the property. Hence, before that stage is reached, pre-investigation mechanism must be applied. Pre-investigation mechanism practised by the Messenger of Allah (p.b.u.h.) and the Companions as well as tabicin clearly shows how important it is to obtain and collect the details specifically about the heirs prior to actual 
investigation is carried out so that allocation of the inheritance can be done fairly thus avoiding ill-treatment and injustice against eligible heirs. This is because Islamic Inheritance Law gives important emphasis to transparency, sincerity and universal justice to all mankind.

\section{Acknowledgement}

This study is financed by the Fundamental Research Grant Scheme (FRGS/1/2013/SSI03/UKM/03/1), UKM; the Research Group of Arabic Culture and Islamic Civilization (KUKAPI, DPP-2014-068), UKM; the Action/Strategic Research Project (PTS-2012-061; PTS-2014-068), UKM; the University-Industry Incentive Grant (INDUSTRI-2012-006), UKM; and the Arus Perdana Project (AP-2012-001; AP-2013-017; AP-2014-006), UKM

\section{References}

'Ali Za'i, Abu Tahir Zubair. (2007). English Translation of Sunan Ibn Majah. Vol. 4. New York: Darussalam. Abu Dawud, Sulayman ibn al-Ash'ath al-Sijistani al-Azdi. (Undated). Sunan Abi Dawud. Vol. 2. Beirut: Dar al-Fikr. al-'Asqalani, Ibn Hajar Ahmad bin 'Ali. (2000). Fath al-Bari bi Sharh Sahih al-Bukhari. Juz 8 \& 13. Beirut: Dar al-Fikr. al-Baqqa'i, Ibrahim ibn Umar ibn Hasan al-Rubat ibn 'Ali ibn Abi Bakr. (Undated). Nazm al-Durar fi Tanasub al-Ayat wa al-Suwar. Vol. 5. Cairo: Dar al-Kitab al-Islami.

al-Bayhaqi, Abu Bakr Ahmad ibn al-Husayn ibn al-'Ali. (1344H). al-Sunan al-Kubra. Vol. 2 \& 6. Hyderabad: Majlis Da'irat al-Ma'arif alNizamiyyah.

al-Bukhari, Muhammad ibn Isma'il. (1422H). Sahih al-Bukhari. Vol. 8. Jeddah: Dar Tawq al-Najah Ibn 'Abidin. (Undated). Hashiyat Radd al-Mukhtar 'ala al-Durr al-Mukhtar. Vol. 4. Cairo: Dar al-Fikr. Ibn Anas, Malik. (2004). al-Muwatta'. Vol. 3. Abu Dhabi: Mu'assasat Zayid ibn Sultan Al Nahyan. Ibn Hanbal, Ahmad al-Shaybani. (Undated). Musnad Ahmad ibn Hanbal. Cairo: Mu'assasat Qurtubah. al-Jurjani, 'Ali bin Muhammad bin 'Ali Abi al-Hasan al-Husaini. (1996). al-Tacrifat. Beirut: 'Alimu al-Kutub. al-Razi, Muhammad bin Abi Bakr bin 'Abd al-Qadir. (1993). Mukhtar al-Sihah. Vol. 1. Cairo: Dar al-Manan. al-Zuhayli, Wahbah. (1996). al-Figh al-Islami wa Adillatuh. Vol. 6. Beirut: Dar al-Fikr. 